\title{
A silvicultura do eucalipto na Região Geográfica Intermediária de Araguaína: implicações socioespaciais sob a ótica do meio técnico-científico-informacional
}

\section{The silviculture of eucalypt plantations in the Intermediate Geographic Region of Araguaína: socio-spatial implications from the perspective of the technical-scientific-informational milieu}

Luciano da Silva Guedes - Doutor em Geografia, pela Universidade Federal de Uberlândia (UFU). Professor Adjunto do Curso de Geografia e do Programa de Pós-Graduação em Demandas Populares e Dinâmicas Regionais (PPGDire) da Universidade Federal do Tocantins (UFT), campus de Araguaína. E-mail: lucianoguedes@uft.edu.br

Saint-Clair Cordeiro da Trindade Júnior - Doutor em Geografia Humana, pela Universidade de São Paulo (USP). Professor Titular do Núcleo de Altos Estudos Amazônicos (NAEA) da Universidade Federal do Pará (UFPA). Pesquisador do CNPq. E-mail: stclair@ufpa.br

\begin{abstract}
Resumo
O presente artigo tem como objetivo abordar a expansão e as implicações socioespaciais do eucalipto na Região Geográfica Intermediária de Araguaína (RGIA), tomando como base teórica o pensamento de Milton Santos quanto ao meio técnico-científicoinformacional e ao uso do território. Foram realizadas incursões a campo nos municípios que vêm se consolidando na produção dessa atividade econômica na região, considerados depoimentos de sujeitos ligados às empresas e de segmentos sociais locais, registros fotográficos, levantamentos de dados secundários e elaboração de mapas, que, em conjunto, permitiram verificar a expansão e a transformação da atividade na região em referência. Os resultados apontaram um crescimento aproximado de 300\% das áreas de eucalipto entre os anos de 2010 a 2020, implicando mudanças na estrutura fundiária regional, impactos em comunidades tradicionais locais, tecnificação e racionalização da paisagem, o que permite concluir que o meio técnico-científicoinformacional se expressa em uma materialidade dialética global/local, em graus de manifestação de verticalidades e horizontalidades no uso do território na área pesquisada.
\end{abstract}

\section{Palavras-chave}

Eucalipto. Uso do Território. Meio Técnicocientífico-informacional. Região Geográfica Intermediária de Araguaína.

\begin{abstract}
Based on a theoretical framework rooted in Milton Santos' thought on the technical-scientificinformational milieu and the use of the territory, the present article aims to approach the expansion and the socio-spatial implications of the eucalypt plantations in the Intermediate Geographic Region of Araguaína (IGRA). A set of methodological procedures, including fieldwork incursions in the municipalities where this economic activity is being consolidated, the collection of oral information from the companies and the affected social groups, the production of photographic records and the elaboration of maps, made it possible to verify the expansion and transformation of the activity in the region. The results showed that the eucalypt areas grew at an approximate rate of $300 \%$ between the years of 2010 and 2020, imposing changes in the regional land-ownership structure, impacts on local traditional communities and the technification and rationalization of the landscape. The results allow to conclude that the technical-scientific-informational milieu expresses itself in a global/local dialectic materiality, in degrees of manifestation of verticalities and horizontalities in the use of the territory in the researched area.
\end{abstract}

\section{Keywords}

Eucalypt. Use of the territory. Technical-scientificinformational milieu. Intermediate Geographic Region of Araguaína. 


\section{INTRODUÇÃO}

O presente texto resulta de pesquisa ${ }^{1}$ que teve como objeto de análise a expansão da silvicultura do eucalipto na Região Geográfica Intermediária de Araguaína (RGIA)². O objetivo foi verificar os principais processos ligados direta e indiretamente a essa cadeia de produção relacionada àquela atividade em nível local/regional, bem como a sua inserção econômica global no atual período técnico-científico-informacional e sua relação com a gestão e uso do território (SANTOS, 2006) $)^{3}$.

A pertinência deste tema está relacionada à abrangência da escala e do recorte espaciais, o que, neste momento, coloca nossa abordagem como panorâmica. Desta maneira, a apreensão maior do fenômeno analisado na RGIA (Mapa 1) deve ser concebida neste estudo como um marco inicial, sem ter a pretensão de solucionar a questão. Portanto, deixa indicativos para a realização de análises futuras como possibilidade de aprofundamento sobre a temática em tela.

Esta reflexão nos autoriza a delimitar nosso objeto de forma temporal e espacial em relação aos elementos componentes da cadeia. Ou seja, estabelecese um recorte do alcance periódico inicial a partir da última década, composto por três segmentações que, mesmo sequenciais, são interdependentes como escopo desta cadeia: o segmento básico, constituído pela produção de mudas; o segmento que abrange a produção das áreas de eucalipto; e o segmento formado pela transformação industrial.

A título de contextualização do fenômeno da silvicultura no Brasil, destaca-se que, de acordo com o IBGE (2017), o País possui cerca de 9,9 milhões de hectares de florestas plantadas voltadas para a produção de celulose, de painéis de madeira, de pisos laminados, de papel, de produção energética e de biomassa, com $76 \%$ desse total correspondendo ao eucalipto. Em comparação com o ano de 2006, segundo a Sociedade Brasileira de Silvicultura (SBS, 2008), a área de florestas

\footnotetext{
Estágio pós-doutoral realizado pelo primeiro autor no Núcleo de Altos Estudos Amazônicos (NAEA), da Universidade Federal do Pará (UFPA), no período de agosto de 2019 a julho de 2020, sob a supervisão do segundo autor do artigo.

2 Nova proposta de Divisão Regional do Brasil elaborada pelo IBGE (2017) em Regiões Geográficas Imediatas e Regiões Geográficas Intermediárias. A Região Geográfica Intermediária de Araguaína é composta por 65 municípios e é uma das três regiões intermediárias do estado do Tocantins.

3 Ao tratar de uma nova concepção acerca da ideia de região, Santos (2006) esclarece que, no período da globalização, este fenômeno mostra-se muito mais complexo devido ao maior volume de eventos no tempo e no espaço, suscitando mudanças repetidas tanto nas formas quanto nos conteúdos das regiões. É à luz desta contribuição que, aqui, estamos pensando o caso em questão, o qual ultrapassa a simples circunscrição territorial/administrativa do estado do Tocantins e compreende parte dos estados do Maranhão e do Pará, portanto, como escala geoeconômica.
} 
plantada no Brasil era de 5,6 milhões de hectares, um aumento aproximado de $77 \%$ em comparação com 2018. No estado do Tocantins, mais precisamente em sua porção norte, a silvicultura do eucalipto vem se consolidando como uma das principais atividades econômicas.

Mapa 1 - Região Geográfica Intermediária de Araguaína (RGIA)

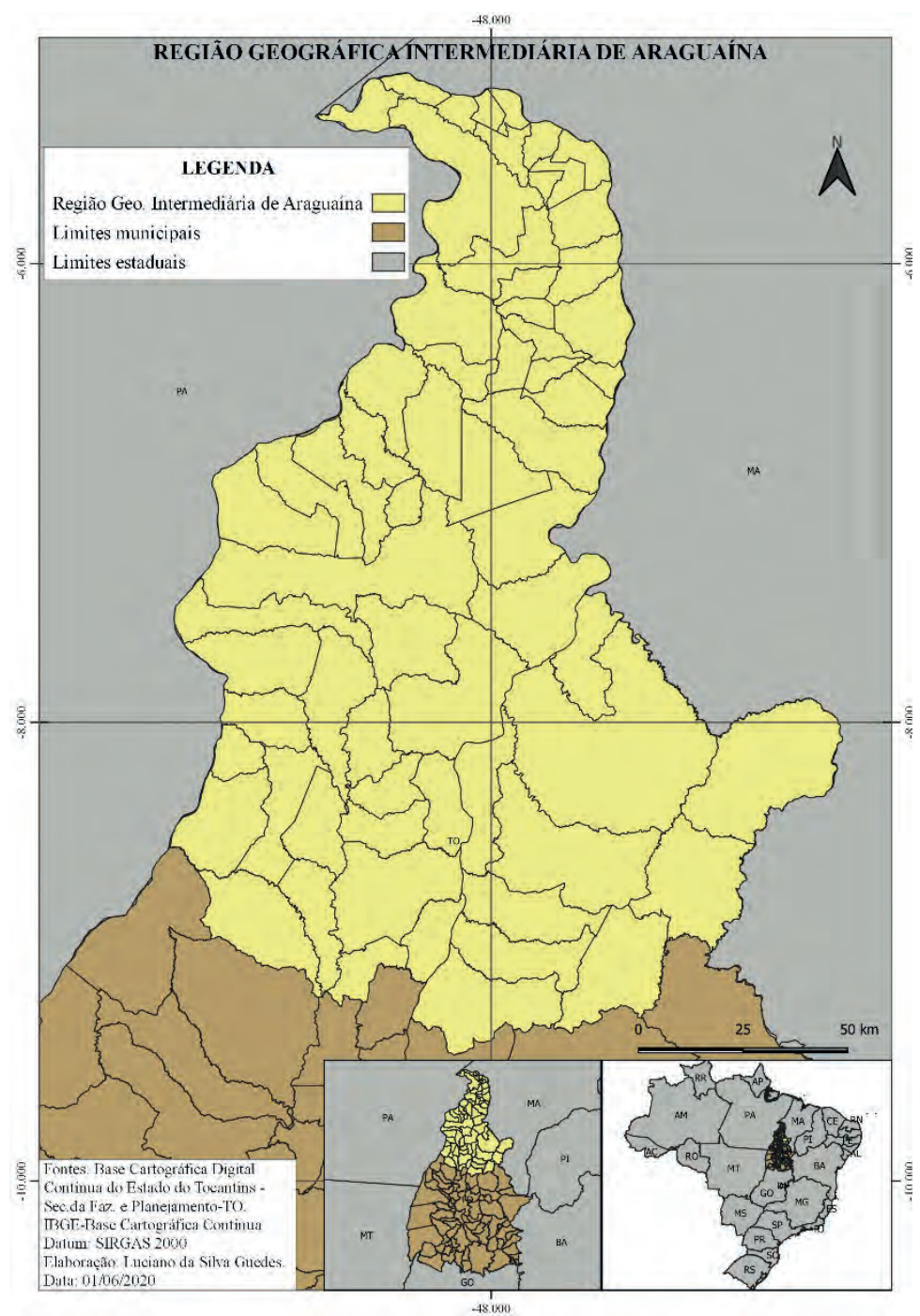

A silvicultura do eucalipto, nas proporções anteriormente referidas, pode ser abordada à luz da discussão dos grandes projetos econômicos e hegemônicos da atual globalização, que, quanto ao uso corporativo do território (SANTOS; SILVEIRA, 2008), refere-se à produção de madeira, à indústria 
moveleira e à siderurgia, reforçando a acumulação capitalista dos grandes agentes hegemônicos. Trata-se de um segmento fortemente vinculado à técnica, à ciência e à informação, tanto em termos de geração de produtos, a exemplo da produção de mudas, quanto em relação à esfera do mercado. Em contrapartida, têm-se como impactos ambientais negativos: a devastação dos ecossistemas naturais, a degradação de recursos hídricos, a desestruturação de sistemas tradicionais de uso da terra, a modernização da propriedade e as migrações campo/cidade, sem que essas possam absorver satisfatoriamente esses fluxos.

Para efeitos de recorte espacial do fenômeno, pensando na divisão do trabalho atribuída à produção da cadeia, podemos delimitar três níveis complementares entre si, quais sejam: o nível da divisão do trabalho atribuído à cidade de Carolina (MA), que detém o empreendimento produtor das mudas de eucalipto; o nível da divisão do trabalho atribuído aos municípios da Região Geográfica Intermediária de Araguaína (TO), relacionado aos produtores das áreas de floresta do eucalipto; e, finalmente, o nível da divisão do trabalho industrial da cadeia, referente às cidades de Imperatriz (MA), com a Suzano Celulose, e de Marabá (PA), com a Siderúrgica Norte Brasil (SINOBRAS). Esses três níveis são complementares e interdependentes como cadeia produtiva em uma hierarquia (SANTOS, 2006).

Os levantamentos de campo realizados ${ }^{4}$, visando à coerência entre teoria e empiria, abrangeram percursos que saíram de Araguaína e seguiram em direção ao extremo norte do município de Araguatins, no estado do Tocantins, no período de setembro a dezembro de 2019. Na oportunidade, coletamos registros de imagens em campo, narrativas de lideranças de comunidades, matérias de jornais e executamos mapeamentos como subsídios às nossas análises. Assim, nessa rota da Região Geográfica Intermediária de Araguaína, pudemos identificar municípios que vêm se consolidando como grandes produtores de eucalipto no estado mencionado, com destaque para Wanderlândia, Darcinópolis, Ananás, São Bento do Tocantins e Araguatins, cujas áreas produtivas são de propriedade das empresas Eco Brasil Florestas S/A, Suzano Papel e Celulose e SINOBRAS Florestal.

No segundo momento de nossa inserção em campo, percorremos a referida rota partindo de Araguaína em direção ao sul da região, passando pelos municípios de Goiatins, de Barra do Ouro, de Filadélfia, de Babaçulândia, de Nova Olinda, de Palmeirante e de Tupiratins, nos meses de janeiro a março de

\footnotetext{
4 Cabe ressaltar que, devido aos protocolos de segurança adotados pelo governo do Tocantins a partir de meados do mês março de 2020, em virtude da pandemia da COVID-19, não foi possível fazer a pesquisa de campo tal como inicialmente planejada, o que nos levou a recorrer a dados secundários sobre informações/relatos das populações impactadas pela atividade da silvicultura em fontes de jornais, sites, material impresso, trabalhos acadêmicos etc.
} 
2020. Nesse momento, realizamos registros de imagens das áreas de fazendas de eucalipto, recolhemos depoimentos de lideranças de comunidades tradicionais e camponesas atingidas e conversas com autoridades políticas, além da aquisição de materiais impressos e da produção de mapeamentos. Este leque de informações levantadas foi sistematizado em gabinete à luz da reflexão teórica, com vistas à produção da versão final do nosso trabalho.

A organização desses levantamentos nos deu base para as análises e as sistematizações que levaram à organização estrutural do texto, que está sistematizado em dois itens, além desta introdução e das considerações finais. Inicialmente discute-se a base teórico-metodológica de abordagem dos conceitos de meio técnico-científico-informacional e território usado e, em seguida, realizase um esforço de aproximação entre teoria e empiria, reunindo as informações coletadas em campo a partir do referencial teórico-conceitual da pesquisa.

\section{MEIO TÉCNICO-CIENTÍFICO-INFORMACIONAL E TERRI- TÓRIO USADO: ELEMENTOS PARA PENSAR A CADEIA DA SILVICULTURA NA REGIÃO GEOGRÁFICA INTERMEDIÁRIA DE ARAGUAÍNA (TO)}

Em sua obra $A$ natureza do espaço, ao falar do meio técnico-científicoinformacional, Santos (2006) menciona a importância da tecnificação do espaço ao longo da história do homem em sua relação com a natureza, criando condições básicas de sobrevivência. Faz isso trazendo uma linha do tempo caracterizada por períodos de evolução tecnológica que definem os processos de produção e de divisão social do trabalho.

No primeiro período, conhecido como meio natural, a base da produção e da reprodução era totalmente dependente dos ciclos da natureza, a exemplo do sistema de pousio no cultivo da terra na agricultura. Os objetos de trabalho criados nesse período eram, em regra, tidos como meras extensões do corpo. As poucas práticas ligadas à produção e à reprodução eram localizadas e fundamentais à reprodução da força de trabalho humano. Trata-se de um período amplo devido ao próprio ritmo das técnicas criadas, que propiciavam mudanças muito elementares sob as práticas humanas de apropriação da natureza como recurso.

A partir do segundo período, classificado pelo autor como meio técnico, os objetos espaciais passaram a ser definidos não somente pela potencialidade natural, mas também por elementos artificialmente criados por sua capacidade inventiva, constituída de conteúdos culturais e técnicos ao mesmo tempo. 
Isso explica, por exemplo, o funcionamento mecânico das máquinas associadas à manipulação humana de operadores. Outros objetos também técnicos, como as ferrovias e as rodovias, passaram a ser extensão do território, relacionados aos avanços tecnológicos desse período. Registram-se também os primeiros indícios de poluição ambiental, resultantes da revolução industrial, da mecanização da terra e do crescimento das cidades. Conforme sua compreensão, esse período técnico se estende do século XIX até as primeiras décadas do século XX.

Vale lembrar que o progresso técnico cumulativo da sociedade marca esse período temporalmente menor em relação ao período natural, porém, com mais densidade técnica na paisagem e na configuração do território, dando grande impulso à dinâmica material da sociedade a partir de então. Esse momento, por sua vez, engloba os chamados períodos do iluminismo e do cientificismo, com grandes avanços assimilados pela ideia de supremacia da sociedade sobre a natureza.

O terceiro período, denominado por Santos (2006) de técnico-científicoinformacional, tem suas origens por volta da Segunda Guerra Mundial. A partir daí, o mundo define um novo ritmo, o mais importante desde o estabelecimento das grandes navegações e que marca a evolução nos campos das ciências, das telecomunicações, da computação, da internet etc.

Sem dúvidas, ao propor tal periodização, Santos (2006) não só desvenda as origens tecnológicas de nosso período, como também sequencia, de forma lógica e coerente, a evolução do processo tecnológico da sociedade no espaço.

Neste período, os objetos técnicos tendem a ser ao mesmo tempo técnicos e informacionais, já que, graças à extrema intencionalidade de sua produção e de sua localização, eles já surgem como informação; e, na verdade, a energia principal de seu funcionamento é também a informação. Já hoje, quando nos referimos às manifestações geográficas decorrentes dos novos progressos, não é mais de meio técnico que se trata. Estamos diante da produção de algo novo, a que estamos chamando de meio técnico-científico-informacional (SANTOS, 2006, p. 159).

O Quadro 1 nos permite uma visualização sumarizada referente à caracterização dos três períodos do meio geográfico, propostos por Milton Santos. 
Quadro 1 - Relação sociedade e espaço em três momentos distintos da história humana

\begin{tabular}{|c|c|c|}
\hline Meio natural & Meio técnico & $\begin{array}{c}\text { Meio técnico-científico- } \\
\text { informacional }\end{array}$ \\
\hline $\begin{array}{l}\text { - Absoluta predominância } \\
\text { das formas da natureza não } \\
\text { bumana; } \\
\text { - Utilização dos recursos sem } \\
\text { grandes transformações do meio; } \\
\text { - Técnica e trabalho com } \\
\text { fácil adaptação às dádivas da } \\
\text { natureza; } \\
\text { - As técnicas não tinham } \\
\text { existência autônoma; } \\
\text { - As sociedades locais como } \\
\text { criadoras das técnicas utilizadas; } \\
\text { - Harmonia sociedade-natureza; } \\
\text { - Racionalidade dominante: } \\
\text { preservação e continuidade do } \\
\text { meio de vida; } \\
\text { - Existência de sistemas técnicos } \\
\text { sem o dominio dos objetos } \\
\text { técnicos. }\end{array}$ & $\begin{array}{l}\text { - Emergência do espaço } \\
\text { mecanizado; } \\
\text { - Os objetos são culturais e } \\
\text { técnicos ao mesmo tempo; } \\
\text { - O espaço: formado pelo } \\
\text { "natural" e pelo "artificial"; } \\
\text { - A diferenciação espacial: } \\
\text { através de próteses do espaço e } \\
\text { da densidade técnica; } \\
\text { - Substituição dos objetos } \\
\text { naturais pelos objetos culturais } \\
\text { e técnicos; } \\
\text { - Surgimento de novas ações que } \\
\text { comandam os objetos técnicos e } \\
\text { dominam os objetos naturais; } \\
\text { - Criação de um novo tempo, } \\
\text { que se superpõe e se contrapõe } \\
\text { aos tempos naturais; } \\
\text { - As lógicas que presidem as } \\
\text { dinâmicas locais passam a ser } \\
\text { exógenas; } \\
\text { - Seletividade espacial dos } \\
\text { sistemas técnicos a determinados } \\
\text { países e regiões. }\end{array}$ & 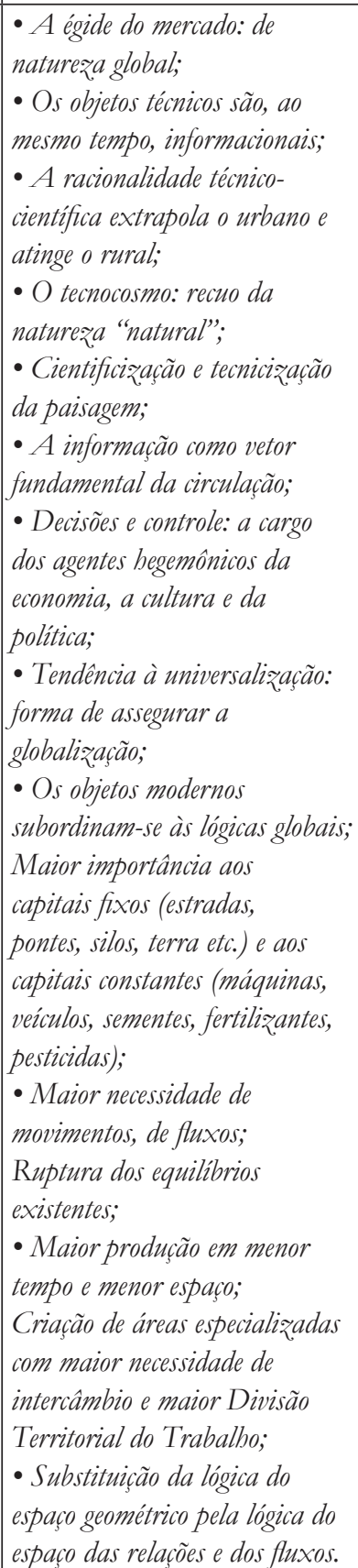 \\
\hline
\end{tabular}

Fonte: elaborado por Saint-Clair C. da Trindade Júnior com base em Santos (2006) 
Composto por altos conteúdos de ciência, de técnica e de informação, isto é, pelas variáveis-chave do período atual, o meio técnico-científico-informacional caracteriza-se como a expressão geográfica do processo de globalização (SANTOS, 2006). Baseado em uma difusão desigual e seletiva nos territórios, esse meio geográfico apresenta-se como instrumental aos mais diversos processos produtivos modernos que se realizam no mundo, sendo mesmo uma base, um substrato para tal.

Quase que em uma espécie de inversão à ordem natural da paisagem, a atual globalização traz uma paisagem informatizada e tecnificada para responder aos anseios dos agentes hegemônicos da produção, reunindo e combinando os objetos e as ações em um movimento praticamente único, capaz de integrar os territórios como condição de sua existência.

Podemos então falar de uma cientificização e de uma tecnicização da paisagem. Por outro lado, a informação não apenas está presente nas coisas, nos objetos técnicos, que formam o espaço, como ela é necessária à ação realizada sobre essas coisas. A informação é o vetor fundamental do processo social e os territórios são desse modo, equipados para facilitar a sua circulação [...] (SANTOS, 2006, p. 160).

Considerando a intermediação da técnica na relação espaço/tempo (SANTOS, 2006), a ideia de território usado (SANTOS, 1999) se coloca como outra importante noção nesta discussão, sobretudo por relacionar a dimensão da experiência vivida à expansão da fluidez territorial como um aspecto (no mais das vezes perverso!) da comunhão global entre objetos e ações; comunhão esta que, mesmo que de forma incompleta, desigual e hierárquica, configura o meio técnico-científico-informacional em determinadas regiões a serviço de agentes que nelas não estão situados. Neste sentido, ao realizar uma leitura do território a partir da dialética Estado e mercado, Santos (2006) nos informa que:

O território como um todo se torna um dado dessa harmonia forçada entre lugares e agentes neles instalados, em função de uma inteligência maior, situada nos centros motores da informação. A força desses núcleos vem de sua capacidade, maior ou menor, de receber informações de toda natureza, tratá-las, classificando-as, valorizando-as e hierarquizando-as, antes as redistribuir entre os mesmos pontos, a seu próprio serviço. Essa inteligência das grandes empresas e dos Estados não é, porém, a única. Em níveis inferiores, o fenômeno se reproduz, ainda que com menos eficácia mercantil (SANTOS, 2006, p. 154).

A partir do que nos ensina Santos (2006), observamos que o território tem sido equipado cada vez mais para atender aos interesses dos grandes agentes 
econômicos, que, situados em outras escalas, veem-no apenas como um mero recurso na busca de mais-valia. Contudo, quando pensamos o território usado, podemos entendê-lo como um espaço banal, que comporta a reprodução de todos os agentes, de todas as empresas, instituições e pessoas, pois:

[...] ele é o quadro da vida de todos nós, na sua dimensão global, na sua dimensão nacional, nas suas dimensões intermediárias e na sua dimensão local. Por conseguinte, é o território que constitui o traço de união entre o passado e o futuro imediatos. Ele tem de ser visto - e a expressão é de François Perroux - como um campo de forças, como lugar do exercício, de dialéticas e contradições entre o vertical e o horizontal, entre o Estado e o mercado, entre o uso econômico e o uso social dos recursos (SANTOS, 1999, p. 19).

Se no passado distante o território estava mais vinculado à ordem fortemente imposta do Estado-nação, cuja materialidade era dada principalmente pelas formas naturais, na atualidade, as ações estão notadamente associadas a um meio técnico-científico-informacional cada vez mais dominante, posto que tais ações sejam realizadas no âmbito dos objetos devidamente sintonizados e carregados de informação.

Para Santos (2006), o território é assim constituído mediante uma lógica normada e normalizadora, entendida como a constante racionalidade da própria informação, como produto inerente aos processos espaciais que envolvem as relações de produção na necessária eficácia que a globalização da economia exige e sem a qual não acontece de maneira satisfatória, já que é espacialmente seletiva e funciona sob a forma de territórios-redes:

Através de ações normadas e de objetos técnicos, a regulação da economia e a regulação do território vão agora impor-se com ainda mais força, uma vez que um processo produtivo tecnicamente fragmentado e geograficamente espalhado exige uma permanente reunificação, para ser eficaz. $O$ aprofundamento resultante da divisão do trabalho impõe formas novas e mais elaboradas de cooperação e de controle. As novas necessidades de complementaridade surgem paralelamente à necessidade de vigiá-las, acompanhá-las e regulá-las. Estas novas necessidades de regulação e controle estrito mesmo à distância constituem uma diferença entre as complementaridades do passado e as atuais (SANTOS, 2006, p. 154).

Com base na citação anterior, podemos afirmar as características recentes que se impõem às novas realidades das cadeias econômicas em suas reproduções ampliadas e interações socioespaciais. Isso porque, uma vez iniciadas, elas tenderão a uma densificação técnica e econômica cada vez mais regulada e vinculada à lógica da ordem global; lógica esta orientada sob a égide dos grandes organismos 
mundiais (Fundo Monetário Internacional, Organização Mundial do Comércio, Banco Mundial etc.), que funcionam como norma e normatização do uso do território no âmbito do Estado territorial. Vale frisar que tais organismos agem para impor a velocidade e a eficácia exigidas pela ordem global na organização e nos usos dos territórios, de modo a consolidar a lógica que, uma vez implantada, exigirá constantes readequações para responder aos imperativos de eficácia exigidos no processo.

Tendo em vista essas considerações, cumpre-nos proceder a uma aproximação da teoria em relação à realidade onde se manifesta a cadeia da silvicultura do eucalipto, recentemente instalada na Região Geográfica Intermediária de Araguaína; esforço este que nos oferece elementos importantes para a aproximação da teoria miltoniana com a empiria relacionada aos atuais processos que vêm acontecendo no Tocantins e em outros estados que lhes são vizinhos, conforme procuraremos mostrar a seguir.

\section{A CADEIA DA SILVICULTURA DO EUCALIPTO NA REGIÃO GEOGRÁFICA INTERMEDIÁRIA DE ARAGUAÍNA: DA ABSTRAÇÃO CONCEITUAL À REALIDADE ABSTRAÍDA}

Santos e Silveira (2008) analisam o Brasil à luz da difusão diferencial do meio técnico-científico-informacional, sem desconsiderar as heranças do passado que ainda resistem no presente. Em nossa discussão, por seu turno, situamos este debate no âmbito dos grandes projetos hegemônicos anteriormente citados, considerando-os como "grandes objetos" (SANTOS, 1995) decorrentes de um sistema de ações projetado em nível global e que se coloca a serviço de políticas econômicas responsáveis por promover seletividades excludentes em face da complexidade que se faz presente no uso do território.

É importante destacar que a abordagem de Santos e Silveira (2008) oferece elementos importantes à análise da composição orgânica do território (SANTOS, 1992) brasileiro e, em particular, à compreensão dos grandes projetos situados em subespaços como a Região Geográfica Intermediária de Araguaína, marcada por notáveis atividades econômicas, como a cadeia da silvicultura do eucalipto, que representa os interesses de agentes hegemônicos que estabelecem diferenciações regionais entre espaços do mandar e espaços do fazer. 
Esses níveis, do mandar e do fazer, estabelecem-se em múltiplas escalas e em diversos segmentos, sejam eles econômicos, políticos e/ou técnicos, a exemplo da cadeia da silvicultura do eucalipto, recentemente implantada na região em referência e que obedece a todos estes critérios: escalas de produção, nível tecnológico de aplicação aos processos, bem como níveis de gestão nas sucessivas etapas, a saber: o início da produção de mudas, a reprodução florestal das diversas áreas, o transporte e o processamento industrial. Assim, nosso foco abrange a empresa Marka Florestal, em Carolina (MA), as áreas de eucalipto da Região Geográfica Intermediária de Araguaína, a fábrica de celulose em Imperatriz (MA) e a de energia de biomassa em Marabá (PA).

Em visita ao Viveiro Marka Florestal, em dezembro de 2020, obtivemos algumas informações que, embora de forma panorâmica, compõem nossas inserções em campo. O viveiro Marka Florestal iniciou suas atividades em Carolina (MA) no ano de 2008 com os sócios Edson Luiz Marchi, ex-colaborador da Suzano Papel e Celulose, e José Vicente e Pedro Benedito de Melo, proprietários da Piraflora, unindo técnica e experiência na produção e comercialização de mudas de eucalipto clonal de alta qualidade.

A Figura 1 revela a dimensão e o porte da empresa Marka Florestal em suas instalações em Carolina (MA). Trata-se de uma área que abrange 15 hectares às margens da Rodovia BR-230 (mais conhecida como Transamazônica), que liga o Nordeste, a partir de João Pessoa (PB), ao interior da Amazônia, situação que contribui para a eficiência da logística de distribuição ao conciliar agilidade, custo e benefícios. A empresa é portadora de uma produção atual de 55 milhões de mudas/ano, gerando 200 empregos diretos e outros indiretos. Sua produção é voltada a uma variedade de eucalipto que mais se adapta às condições edafoclimáticas da região do cerrado, propiciando melhor qualidade à celulose e à geração de energia (MARKA FLORESTAL, 2020).

Nesse ponto de vista, a figura, a seguir, chama-nos a atenção para a aplicação da técnica, da pesquisa e do investimento na produção de mudas, reforçando o valor da investigação genética que não está desvinculada das condições físiconaturais do cerrado, como as próprias informações coletadas em campo nos asseguraram. Destarte, a associação entre a ciência e a informação, bem como entre os aspectos da logística e da escala de produção, dada a quantidade de produção de mudas, são elementos essenciais ao sucesso da produtividade na base da cadeia. 
Figura 1 - Vista aérea do viveiro da Marka Florestal de produção de mudas de eucalipto na cidade de Carolina (MA)

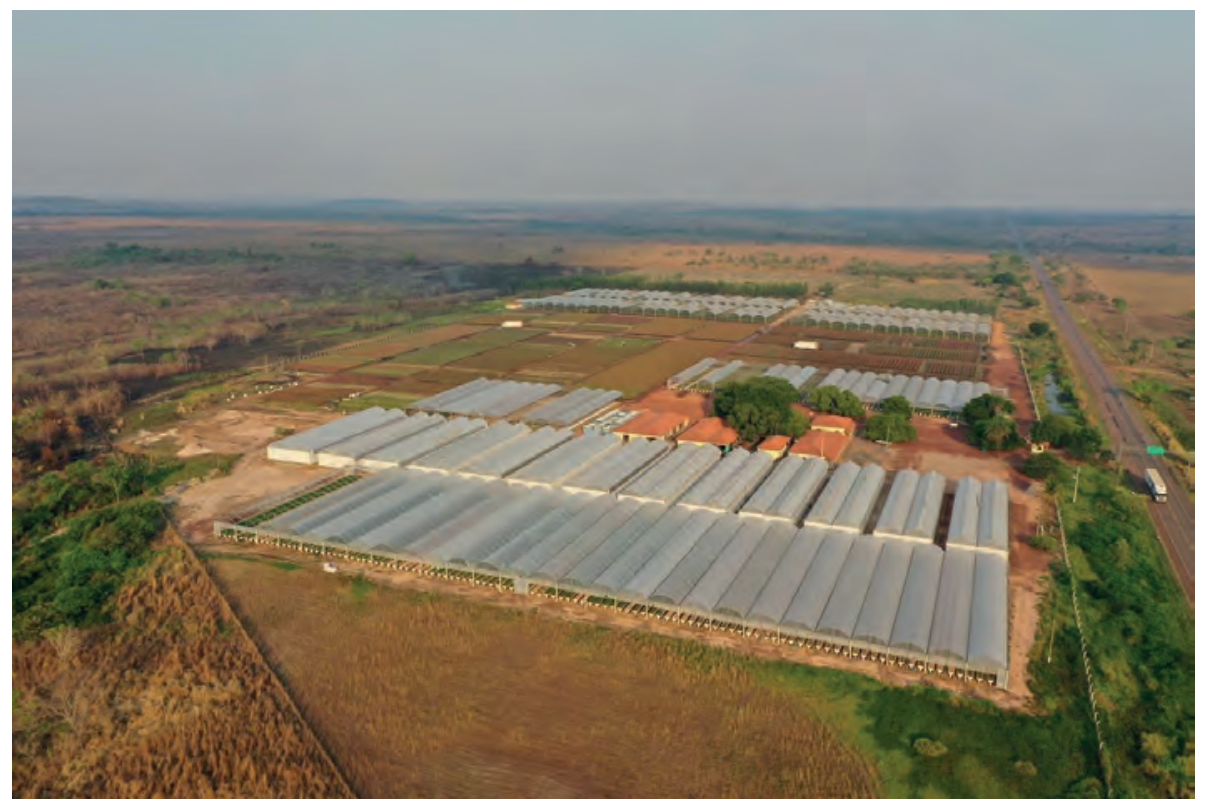

Foto: Linkedin (2020)

Podemos afirmar que esta empresa, como o grande agente hegemônico iniciador desta cadeia, é concebida como um "grande objeto" (SANTOS, 1995) no âmbito das ações inerentes ao território usado, de acordo com a concepção de Santos (1999, 2006). Nesta perspectiva, a seguinte citação do autor nos ajuda a refletir sobre a geração das mudas de eucalipto como base da cadeia:

[...] da mesma forma como participam da criação de novos processos vitais e da produção de novas espécies (animais e vegetais), a ciência e a tecnologia, junto com a informação, estão na própria base da produção, da utilização e do funcionamento do espaço e tendem a constituir o seu substrato (SANTOS, 2006, p. 160).

A forma cumulativa e qualitativa do progresso tecnológico - que tem o vetor informacional como motor de funcionamento - está presente nos processos produtivos, na cidade ou no campo, nos objetos tecnológicos, como uma hidrelétrica, uma metrópole, mas também em áreas de eucalipto que compõem a cadeia produtiva da silvicultura. Ressaltamos que esta cadeia é o foco de nossa pesquisa, englobando a produção de mudas, as áreas extensivas destinadas ao cultivo e o manuseio do replantio, elementos que demandam a aplicação de técnicas ligadas ao preparo do solo e garantem: a) a padronização 
em relação ao tempo de crescimento das plantas; b) o manejo da árvore madura no seu corte; e c) o próprio transporte sob a força de modernas máquinas e extensos e potentes caminhões. Vale mencionar que estes veículos transportam as toras desde as florestas até a indústria e, a partir desse estágio, encaminham o processamento industrial do eucalipto na produção da celulose e da biomassa para geração de energia.

Na sequência, demonstramos, por meio da Figura 02, os canteiros de mudas de eucalipto que expressam a escala de produção de mudas alimentadoras das inúmeras áreas de eucalipto espalhadas pelos municípios da Região Intermediária de Araguaína.

Figura 2 - Canteiros de mudas de eucalipto na empresa da Marka Florestal Carolina (MA)

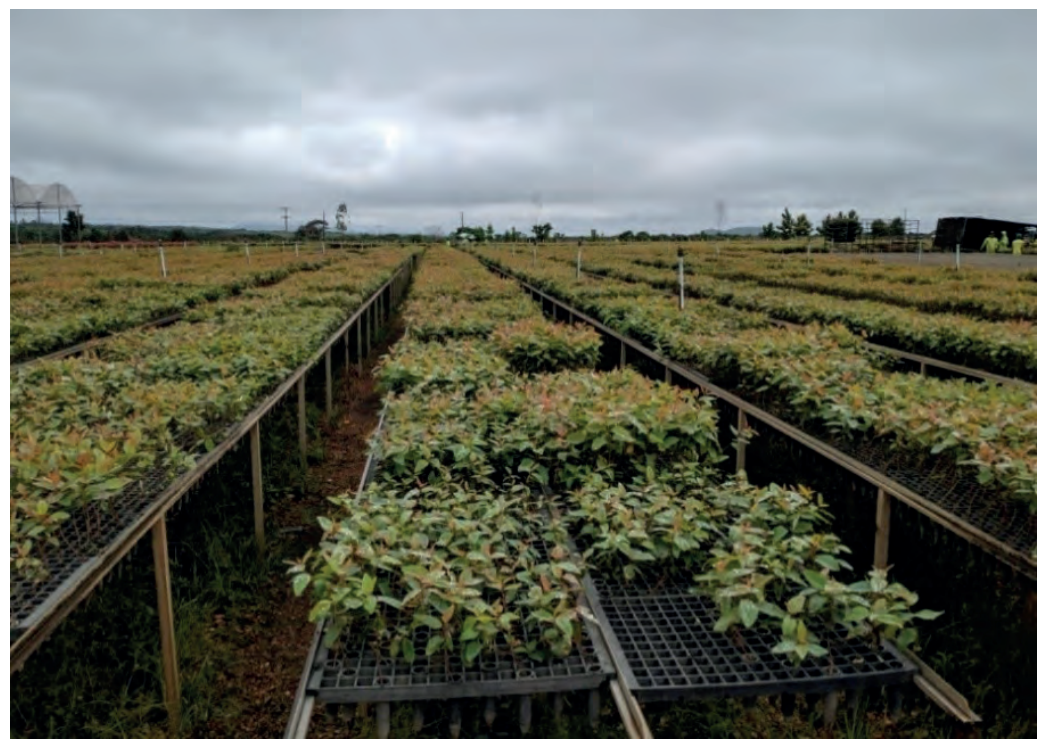

Foto: Luciano Guedes (dezembro de 2020)

Nesse sentido, pensando o uso do território a partir da dinâmica indissociável entre sistema de objetos e sistema de ações (SANTOS, 2006), a cadeia da silvicultura pode ser compreendida como um sistema de objetos em que cada elemento corresponde aos propósitos das ações executadas sob seus respectivos graus técnicos, científicos e informacionais, a exemplo do que ocorre com a produção das mudas. Este é um subsistema a compor o todo da cadeia, como também são as áreas do eucalipto com os processos inerentes, conforme abordamos na sequência, funcionando como outros subsistemas intermediários entre a produção das mudas e o processamento industrial. 
Necessário se faz afirmar que essa atmosfera tecnificada impulsiona o rápido incremento à materialidade do território, trazendo como resultado a valorização econômica da instituição da propriedade moderna e privada da terra, o que tem levado a perdas territoriais de segmentos de populações tradicionais, indígenas e camponesas de suas posses de terra, como é o caso da Comunidade Quilombola Grotão, no município de Filadélfia (TO) (MATOS, 2018), uma vez que estas populações não estão em sintonia com essa lógica da globalização econômica no âmbito da silvicultura do eucalipto. Nesse contexto, parece-nos oportuna a citação de Santos:

Eis porque os territórios nacionais se transformam num espaço nacional da economia internacional e os sistemas de engenharia mais modernos, criados em cada país, são mais bem utilizados por firmas transnacionais que pela própria sociedade nacional. Em tais condições, a noção de territorialidade é posta em xeque e não falta quem fale em desterritorialização [...] (SANTOS, 2006, p. 162).

De acordo com o anuário da Associação Brasileira de Produtores de Florestas Plantadas (ABRAF, 2012), os estados de Minas Gerais, de São Paulo, do Paraná, de Santa Catarina, da Bahia, do Mato Grosso do Sul e do Rio Grande do Sul são os que possuem a maior concentração de plantios florestais no Brasil, com $87,1 \%$ da área total. A maior concentração nas regiões Sul e Sudeste do País $(72,3 \%)$ se justifica em função da localização das principais unidades industriais dos segmentos de celulose e papel, de painéis de madeira industrializada, de siderurgia a carvão vegetal e madeira mecanicamente processada.

A pesquisa de Carvalho et al. (2019) demostrou que no ano de 2004 o estado do Tocantins apresentou uma área de florestas plantadas na ordem de 17.414 hectares. No ano de 2013, esse quantitativo passou para 105.989 hectares distribuídos em 287 fazendas. Desse total, 96.459 hectares são de eucalipto, representando $91 \%$ das florestas plantadas no estado. Esses dados demonstram um aumento aproximado de 600\% em nove anos.

Os dados levantados para este estudo demonstraram a expansão das áreas de eucalipto no período de 2010 a 2020, conforme procuramos representar nos mapas 2 e 3. Assim, em 2010, a área territorial ocupada por fazendas de eucalipto era de aproximadamente 28.000 hectares, enquanto no ano de 2020 essa área já está em torno de 93.000 hectares. Ou seja, um crescimento de mais de 300\% em dez anos, o que pode ser percebido pelo aumento das áreas em amarelo nos respectivos mapas.

Nos últimos anos, os estados do Tocantins e do Mato Grosso do Sul são os que mais vêm apresentando crescimento dessa atividade, transformando-se, 
juntamente com o Maranhão e com o Pará, nas novas fronteiras de florestas plantadas no Brasil. Para Fornaro (2012), além da disponibilidade de terras por valores ainda competitivos no Brasil nesses estados, comparativamente a outros onde a agricultura empresarial tecnologicamente intensiva já se consolidou, outros fatores explicam o avanço dessa atividade, como a existência de espécies de árvores com adaptabilidade para o clima de cerrado, a construção da Ferrovia Norte-Sul e a presença de rodovias importantes que cortam esses estados e que viabilizam o fluxo logístico da matéria extraída.

Mapa 2 - Áreas de eucalipto na RGIA Mapa 3 - Áreas de eucalipto na RGIA no ano de 2010 no ano de 2020
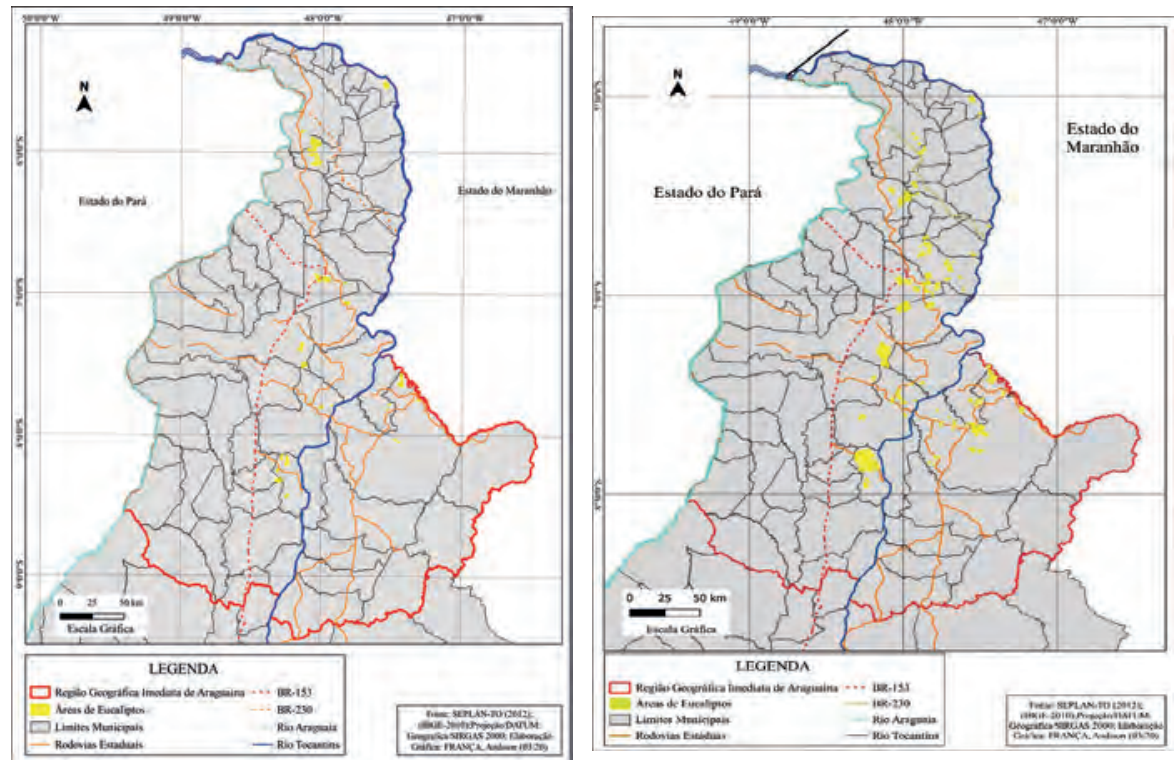

No caso do Tocantins, destaca-se a aprovação da Lei Estadual n ${ }^{\circ} 2.713$, de 09 de maio de 2013 (TOCANTINS, 2013), que dispensa a necessidade de licenciamento ambiental para o desenvolvimento de atividades agrossilvipastoris, conforme análise de Vampré e Medina (2019).

A legislação de favorecimento, neste caso, diz respeito ao território normado de que tematiza Santos (2006), posto que se trata de uma forma que legaliza a implantação da ordem hegemônica e, de tal modo, evidencia que o Estado está a serviço da burguesia capitalista global. Incentiva-se, nesse sentido, uma competitividade dos lugares, momento em que se observa um escancaramento legal do território à imposição da ordem global, a razão que, em detrimento da ordem local, orienta a atuação dos grandes agentes econômicos no espaço. 
Nesse particular, o surgimento de novos espaços de produção (ELIAS, 2006) amplia-se e inclui áreas até então pouco favoráveis à obtenção de alta lucratividade.

As novas possibilidades de fluidez do espaço, somadas às que a revolução tecnológica vem propiciando à intensificação da forma capitalista de produzir na agropecuária, promovem verdadeira reestruturação produtiva no setor. A partir desta reestruturação, muitos novos espaços agrícolas podem ser incorporados à produção e ao consumo agropecuários globalizados (ELIAS, 2006, p. 31).

Especificamente na RGIA, dois fatores podem explicar o crescimento da produção de eucalipto. Um é a proximidade com a fábrica de celulose da Suzano, localizada na cidade de Imperatriz, no Maranhão, que absorve grande parte da produção. A outra razão é a presença do polo siderúrgico da Siderúrgica SINOBRAS, localizado na cidade de Marabá, no estado do Pará, outro destino bastante comum para os produtores localizados mais ao norte.

De acordo com o IBGE (2010), observamos que São Bento do Tocantins (TO) vem se destacando não só como área de plantio de eucalipto, mas também no campo do processamento industrial. Isso porque o município contou com a instalação de uma unidade da SINOBRAS, com sede regional em Marabá (PA); evento que afetou diretamente a dinâmica daquele pequeno município, especialmente no que tange à geração de impostos e à absorção da mão de obra local na produção de redutor bioenergético, que é destinada à Marabá.

Em visita à SINOBRAS, em São Bento do Tocantins, constatamos que esta empresa gera em torno de 200 empregos diretos no município. Além de sua produção direta, esta, com sede regional em Marabá, compra carvão de pequenos e de grandes produtores dos estados do Tocantins e do Pará. Em consequência, o plantio do eucalipto por outros colaboradores é somado às suas operações sazonais, sob a alegação do discurso de que mantém uma aproximação com as comunidades locais, anulando a ideia de existência de conflitos com elas em sua área de atuação.

Em relação à atividade no município de Araguatins (TO), próximo de São Bento do Tocantins, tem-se que, dos 18.000 hectares em plantação de eucalipto, 13.000 hectares são destinados à produção e ao fornecimento de carvão à siderúrgica SINOBRAS em Marabá (PA), conforme informações da empresa.

As diversas áreas de eucalipto que apresentamos evidenciam que o que menos aparece é a natureza original, ratificando a afirmação de uma tecnificação da paisagem configurada no âmbito do meio técnico-científico-informacional. A referida paisagem apresenta-se na evolução do processo de produção das áreas do 
eucalipto, isto é, da floresta em pé até o transporte da madeira. Tal evolução, por sua vez, pode ser identificada no mosaico sintetizado na Figura 3, que apresenta características diferentes da cadeia da silvicultura e relaciona as áreas de produção das florestas e o aspecto da logística do transporte.

Figura 3 - (a) Floresta de eucalipto no município de São Bento do Tocantins; (b) toras de eucalipto após o corte, empilhadas e enfileiradas para o transporte; (c) procedimento de carregamento para o transporte; (d) veículo utilizado para transporte da madeira de eucalipto

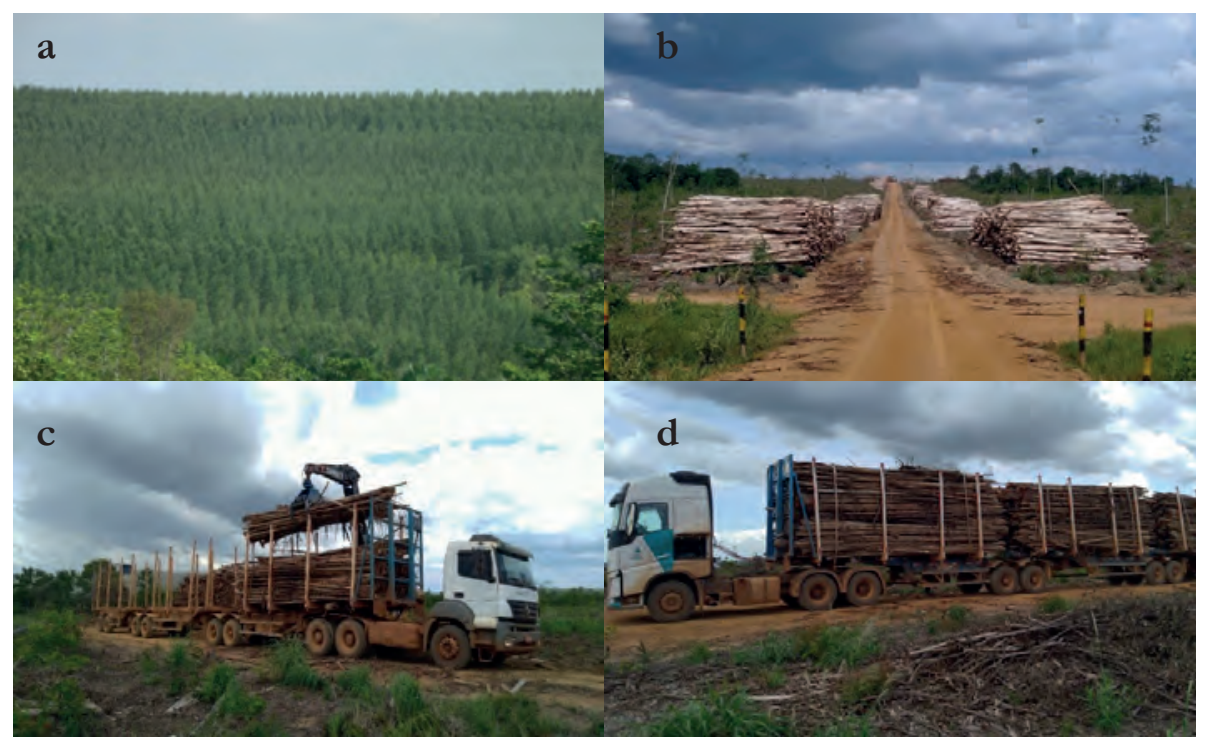

Fotos: Luciano Guedes (setembro de 2019 e fevereiro de 2020)

Como segmento da cadeia, a logística também está presente em diferentes níveis e escalas, tal como podemos observar na figura anterior, com a representação das toras disponibilizadas às margens da estrada de terra, que, mesmo não asfaltada, apresenta bom estado de conservação (Figura 3-b); constatação esta que indica como a cadeia se vale de diversos graus de técnicas aplicadas ao transporte, em fluidez de tempos/espaços diversos. Nessa paisagem tecnificada, o trabalho e as funções obedecem à informação e à qualificação do trabalho, como demonstra a Figura 3-c, na qual um operador controla a máquina no carregamento das toras do chão para o treminhão.

Enquanto um dos subsistemas da cadeia do eucalipto, a logística se sustenta basicamente no transporte rodoviário em várias rodovias estaduais e federais, a exemplo da TO-222, que conecta as cidades de Araguaína (TO) e de Carolina (MA), e estas à BR-153, que, por sua vez, liga Araguaína à Imperatriz 
(MA). Como território usado da silvicultura, esse sistema rodoviário é integrado também pela BR-230, que liga Carolina (MA) à Araguaína (TO) pela TO-222 e à Imperatriz (MA), pela BR 153; liga-se também às áreas de eucalipto de Wanderlândia (TO), de Araguatins (TO) e de Marabá (MA) por meio da BR230. Para Fornaro (2012), soma-se a esse sistema rodoviário a BR-226, que se funde à Rodovia Belém-Brasília (BR-010), partindo da conexão com a BR-153 no município de Wanderlândia (TO), e segue até o município de Aguiarnópolis (TO), na divisa com o estado do Maranhão.

Ressaltamos que essas rodovias são os principais meios para os fluxos de transporte da madeira do eucalipto, perpassando as áreas de eucalipto para a fábrica de celulose da Suzano, na cidade de Imperatriz (MA), e para a siderúrgica SINOBRAS, na cidade de Marabá (PA).

Em relação ao meio técnico-científico-informacional, Santos (2006) também chama a atenção para a crise ambiental gerada pela própria rapidez das mudanças decorrentes do uso do território pelos agentes hegemônicos, cujas ações impactam tanto a ordem local quanto o equilíbrio ambiental referente à modernização da terra, à produção e às relações de trabalho, afetando, consequentemente, as territorialidades das populações nativas, tradicionais e camponesas.

[...] a busca de mais-valia ao nível global faz com que a sede primeira do impulso produtivo (que é também destrutivo, para usar uma antiga expressão de J. Brunhes) seja apátrida, extraterritorial, indiferente às realidades locais e também às realidades ambientais. Certamente por isso a chamada crise ambiental se produz neste período histórico, onde o poder das forças desencadeadas num lugar ultrapassa a capacidade local de controlá-las, nas condições atuais de mundialidade e de suas repercussões nacionais (SANTOS, 2006, p. 170).

Indagadas sobre a presença da SINOBRAS em São Bento do Tocantins (TO), lideranças de comunidades tradicionais relataram que a empresa trouxe crescimento econômico para o local em razão da geração de emprego no município. No entanto, também reclamaram que alguns córregos estão secando depois da chegada do eucalipto no local. Outra questão levantada foi a preocupação com a expansão do eucalipto sobre as áreas de babaçu, que já começa a afetar a principal fonte de renda de várias famílias.

Registramos outra situação dos impactos decorrentes da silvicultura na comunidade tradicional Sete Barracas, localizada no munícipio de São Miguel do Tocantins, na região conhecida como Bico do Papagaio. Na ocasião, tomamos conhecimento das ações da Sra. Raimunda Gomes da Silva, falecida em novembro de 2018. "Dona Raimunda Quebradeira de Coco", como 
era conhecida, deixou um legado na atuação pelos direitos das mulheres quebradeiras de coco babaçu nessa região, com destaque para a criação de sindicatos de quebradeiras de coco, como o do Movimento Interestadual das Quebradeiras de Coco Babaçu (MIQCB).

Nesse sentido, contrariamente à chegada do eucalipto e à modernização da paisagem, há que se reforçar a gestão política no âmbito da produção local em detrimento do desmantelamento dessa organização; gestão política esta que fora perturbada pelos impactos da chegada do eucalipto como um modelo da racionalidade global que age de forma fria e excludente do ponto de vista social e ambiental, uma vez que as matas de cocais do babaçu, duramente ameaçadas por aquele processo, caracterizam-se como outras formas diferenciadas de uso do território, sendo fontes de renda das famílias dessa comunidade.

A matéria da Associação União das Aldeias Apinajé (PEMPXÀ, 2015) traz uma forte denúncia sobre os impactos negativos da silvicultura do eucalipto nos territórios indígenas, dando conta dos desmandos da política dirigida a esses povos conciliados com as inoperâncias e/ou os favorecimentos aos agentes hegemônicos no atendimento dos seus interesses imperativos, os quais somente prejudicam os povos nativos da região.

Atualmente estamos sendo fortemente pressionados e prejudicados por grandes desmatamentos realizados por empresas para o plantio de eucaliptos e carvoarias. O Relatório do Ministério Público Federal-MPFAGA divulgado em 2013, apontou 494 projetos de "silvicultura" das empresas Eco Brasil Florestas, Suzano Papel e Celulose e Sinobrás em andamento no Norte de Tocantins, sendo que mais da metade destes empreendimentos estão planejados e sendo implantados nos municípios de Ananás, Araguatins, Axixá, São Bento do Tocantins, Cachoerinha, Nazaré e Tocantinópolis, alguns com incidência direta na Terra Apinajé. No mês de agosto de 2013, após denuncia do povo Apinajé, a Fundação Nacional do Índio-FUNAI e a Companhia de Polícia Rodoviária Ambiental do Tocantins - CIPRA, durante diligencias em áreas limítrofes flagraram um desmatamento irregular na fazenda Gleba Matão I, localizada na BR 230, em área reivindicada pela comunidade Apinajé, no qual existiam também (2) duas carvoarias em operação. Argumentando a não participação no Processo de Licenciamento dos empreendimentos, a FUNAI conseguiu junto ao MPF-AGA que os referidos desmatamentos e carvoarias fossem embargados pelo Naturatins, que é órgão licenciador do Estado do Tocantins. Mas, por meio de Decisão Judicial, o empreendedor obteve autorização para continuar as atividades, que estão se expandindo por toda região do entorno da Terra Apinajé, visando o plantio de eucaliptos (PEMPXÀ, 2015, p. 2-3). 
A outra situação que representa o grau dos rápidos impactos quanto ao avanço do eucalipto sobre o território ancestral é a registrada na Comunidade Quilombola Grotão, localizada no município de Filadélfia (TO). A área plantada de eucalipto invadiu grande parte do território quilombola, ocasionando uma drástica redução do seu território ancestral. A área de plantio de eucalipto está próxima da comunidade, já impactando a oferta de água. Isso tem provocado a migração de parte das famílias para cidades da região, como Araguaína (TO), ocasionando a perda da força e expressão culturais que têm alterado o curso de normalidade da vida comunitária, desestabilizando o desenvolvimento socioambiental (MATOS, 2018).

Os impactos ocorrem até mesmo no âmbito da ordem oficial dos territórios municipais institucionalizados, ultrapassando as escalas das populações nativas, tradicionais e camponesas, como é o caso da prefeitura de Palmeirante (TO), onde um representante do poder público local nos informou que no ano de 2007 a empresa Eco Brasil começou a comprar terras no município junto a pequenos e grandes proprietários. Em 2008, deu-se início ao preparo do solo e à implantação da logística para o plantio do eucalipto nas áreas adquiridas.

A sua narrativa é contundente ao manifestar seu sentimento de decepção com os rumos que a atividade de silvicultura ganhou no município. Para ele, em um primeiro momento, a empresa conseguiu convencer alguns pequenos proprietários a venderem suas terras por valor acima do mercado local. Desestimulados pela falta de incentivos para permanecerem em suas terras e seduzidos pela possibilidade de ganharem dinheiro, desfizeram-se do seu bem e terminaram por gastar o dinheiro da venda, não conseguindo mais adquirir outra terra. Com isso, muitos se "refugiaram" no distrito de Cicelândia, onde vivem de suas aposentadorias ou de pequenos serviços oferecidos à população de Palmeirante.

Outro ponto observado no município foi o não cumprimento das promessas realizadas em audiências públicas promovidas pela empresa, que, na ocasião da chegada do eucalipto, criaram expectativas na população e no poder público de melhorias sociais e econômicas ao município com a atuação da empresa. No entanto, para o poder público, a Eco Brasil Florestas só gera algum tipo de retorno econômico no recolhimento do Imposto sobre a Propriedade Territorial Rural (ITR), o que não corresponde à responsabilidade social que a empresa pregou e prega nos seus discursos.

Esse panorama geral, demonstrativo dos impactos negativos no âmbito da cadeia da silvicultura do eucalipto na Região Geográfica Intermediária de Araguaína, caracteriza algumas das contradições relacionadas aos mais recentes impulsos da nova ordem global sobre as condições até então expressas nos 
modos de vida locais, cujos descontentamentos são verificados por meio das impressões coletadas em campo.

Nesse sentido, Santos (2006) lembra que a modernização, a urbanização e a ideia de progresso chegam com muito mais impacto de transformação socioespacial em espaços que ele classifica como opacos no contexto do meio técnico-científico-informacional. O referido autor lembra, também, que isso se efetiva com maior força em espaços com pouca densidade técnica, oriundos da organização política e econômica precedente.

No que concerne aos níveis de divisão do trabalho que a cadeia da silvicultura do eucalipto da Região Geográfica Intermediária de Araguaína abrange e à formação de uma hierarquia interdependente e complementar, cumpre-nos trazer uma reflexão relacionada ao nível industrial da produção, mesmo que de forma panorâmica. Neste sentido, as palavras de Santos (2006) são oportunas como embasamento:

Essas interdependências tendem a serhierárquicas e seu papel de ordenamento transporta um comando. A hierarquia se realiza através de ordens técnicas, financeiras, políticas, condição de funcionamento do sistema. A informação, sobretudo ao serviço das forças económicas hegemônicas e ao serviço do Estado, é o grande regedor das ações que definem as novas realidades espaciais. Um incessante processo de entropia desfaz e refaz contornos e conteúdos dos subespaços, a partir das forças dominantes, impondo novos mapas ao mesmo território. E o crescente processo de homogeneização se dá através de um processo de hierarquização crescente. A homogeneização exige uma integração dependente, referida a um ponto do espaço, dentro ou fora do mesmo país. Nos outros lugares, a incorporação desses nexos e normas externas tem um efeito desintegrador das solidariedades locais então vigentes, com a perda correlativa da capacidade de gestão da vida local (SANTOS, 2006, p. 193).

A reflexão de Santos (2006) nos viabiliza a compreensão de que a cadeia do eucalipto aqui abordada tem um recorte cartograficamente mais direto, sobretudo porque optamos por abordar as transformações mais aparentes relacionadas às duas etapas iniciais da cadeia, quais sejam: a empresa de produção de mudas em Carolina (MA) e as áreas de cultivo do eucalipto com impacto direto no norte tocantinense.

Entretanto, essa cadeia tem seu sustentáculo no empreendimento industrial do imigrante ucraniano Leon Feffer, fundando em 1924 a Suzano Celulose e Papel, com inauguração, dezessete anos depois, da primeira fábrica no bairro do Ipiranga, em São Paulo (SP) (SUZANO, 2020). Ainda de acordo com esta fonte, a referida empresa, de atuação global, é marcada por uma trajetória ascendente 
de industrialização, de diversificação, de fusão e de incorporação de outras empresas, bem como de crescente aplicação técnica de suas linhas de produção e de diversificação de produtos.

Para Santos (2006), os agentes hegemônicos da globalização detêm grande capacidade de alterar a ordem local dos lugares onde determinam seus usos corporativos do território. Desta maneira, a cadeia aqui estudada não se explica sem o comando desse importante agente hegemônico instalado em Imperatriz (MA) no ano de 2014, considerada umas das maiores e mais modernas plantas de produção de celulose e de fibra curta do mundo, ainda que sua presença na região seja anterior à instalação da sua fábrica. Sua fusão com a Aracruz celulose, em 2017, torna essa empresa a maior produtora de celulose do mundo.

A matéria de Vera Batista, divulgada pelo Correio Brasiliense (BATISTA, 2014), traz informações a respeito da Suzano Celulose, especialmente no âmbito da cadeia da silvicultura do eucalipto na Região Geográfica Intermediária de Araguaína, informando sobre: a) a instalação e as características da fábrica, em Imperatriz (MA); b) a produção regional da matéria-prima de abastecimento da indústria; e c) a exportação da produção industrial conectada ao porto de Itaqui/ São Luís (MA), via ferrovia Norte/Sul e Carajás.

A Suzano Papel e Celulose inaugura, nesta quinta-feira (20/3), a fábrica de produção de eucalipto em Imperatriz, segunda maior cidade do Maranhão, com a presença da presidente Dilma Rousseff e da governadora, Roseana Sarney. A unidade tem capacidade de produção de 1,5 milhão de toneladas. A fábrica, que já está em operação, atenderá, prioritariamente, os mercados europeu e norte-americano. $\mathrm{O}$ empreendimento recebeu investimentos de $\mathrm{R} \$ 6$ bilhões.

O suprimento de madeira virá de plantios próprios, do Programa Vale Florestar e de parcerias com produtores locais. A planta industrial tem duas secadoras e dois fornos de cal, que permitem maior flexibilidade e estabilidade operacional. 'Esse é um momento muito especial e que representa um salto importante para a empresa. Superamos o primeiro desafio, que era o início da produção, e agora estamos com nossas equipes focadas na evolução da planta'; explicou Walter Schalka, presidente da Suzano Papel e Celulose.

Para escoar a celulose, serão utilizados um ramal ferroviário próprio de 28 quilômetros, a ferrovia Norte-Sul e a ferrovia Carajás, essas duas últimas administradas pela Vale. A carga não sofrerá transbordo até o Porto do Itaqui, por onde será exportada. Serão gerados 3,5 mil empregos diretos e 15 mil indiretos (BATISTA, 2014, não paginado).

No que se refere à produção de eucalipto, a reportagem menciona as parcerias entre os produtores locais nas áreas de eucalipto da Região Geográfica Intermediária de Araguaína, já que o processamento industrial em grande escala 
demanda cultivo de grandes produtores individuais no entorno regional, além dos grandes produtores deste contexto, representados pelas empresas Eco Brasil e SINOBRAS. Quanto ao transporte e à exportação da produção, a reportagem também se refere à integração que associa a Suzano, responsável pela produção de celulose, e a Vale, que detém o monopólio do transporte ferroviário ligando imperatriz ao porto de Itaqui, em São Luís (MA), mediante uma logística viabilizada pelas ferrovias Norte-Sul e Carajás; modalidade esta que é considerada uma das formas de transportes mais baratas do mundo.

Toda cadeia apresenta uma complexidade produtiva dinâmica, ou seja, assume relações complexas, diversas, em multiatividades e multiescalaridades de formas integradas, como é o caso da cadeia do eucalipto aqui em questão. Neste sentido, o eucalipto também serve de matéria-prima à produção de bioenergia, tão essencial à produção do aço, que no caso da SINOBRAS, em Marabá (PA), também começa a se configurar como outra cadeia, a do aço. Particularmente, essa siderúrgica utiliza o eucalipto com Unidade de Produção de Redutor Bioenergético (SINOBRAS, 2010).

Com matriz em Fortaleza (CE) e siderúrgica em Marabá (PA), a SINOBRAS possui 13 fazendas próprias no estado do Tocantins com plantio de eucalipto, somando uma área de 24.000 hectares. Recentemente, escolheu dentro do Tocantins o município de São Bento do Tocantins para investir em sua unidade industrial de produção de Redutores Bioenergéticos, a fim de atender sua unidade siderúrgica em Marabá. A unidade industrial da SINOBRAS em São Bento conta com duas unidades cuja capacidade de produção é de 25.500 metros cúbicos. Está equipada com 46 fornos retangulares para mitigarem os impactos ambientais. É uma empresa que aplica a mecanização em suas operações, nos módulos referentes à colheita, ao transporte, ao manejo da lenha e ao carvão mecanizados. Gera 200 empregos diretos, além dos empregos temporários, nos períodos de plantio (SINOBRAS, 2010).

Segundo as informações contidas no seu Relatório de Sustentabilidade (SINOBRAS, 2010), esta empresa é coerente com seus princípios de sustentabilidade ao empreender a política econômica em Redutores Bioenergéticos e ao implantar suas fazendas florestais, localizadas nos municípios tocantinenses de São Bento do Tocantins e Araguatins. Compondo 24 mil hectares que geram um saldo de 16 milhões de árvores, estas fazendas garantem 100\% da demanda de utilização desse produto no processo da usina siderúrgica em Marabá (PA). Dessa maneira, com o plantio de outras 50 mil mudas, a empresa afirma que garante as áreas de preservação permanente. 
A partir dos dados coletados, o que se pode verificar na cadeia da silvicultura do eucalipto da Região Intermediária de Araguaína é que a ciência, a técnica e a informação são ingredientes essenciais do discurso da produção, da sustentabilidade e da legitimidade do processo; discurso este que está presente no processo de modernização, de padronização e de uniformização do espaço e no uso do território, tendo a mídia na base da comunicação e como agente veiculador, já que é inerente, em princípio e em última instância, ao mercado global.

\section{CONSIDERAÇÕES FINAIS}

Ao final da nossa reflexão, achamos pertinente realçar alguns pontos desenvolvidos, mas também deixar alguma situação na perspectiva de futuro retorno ao tema, considerando tanto a dinâmica particular da cadeia quanto a dialética do conhecimento científico.

Partindo de informações gerais, empíricas e também de leituras teóricas, a primeira questão que trouxemos em nossa proposta era se havia uma cadeia do eucalipto na Região Geográfica Intermediária de Araguaína. E a conclusão é sim, há uma cadeia produtiva nesse segmento, ainda que embrionária, considerando as características mais marcantes que registramos em campo. Tais peculiaridades puderam ser expressas com base nos processos, nos atores e nos níveis de ocorrência em suas evidências, tanto em relação aos impactos sobre a modernização da terra, como no que diz respeito às dinâmicas campo/cidade que evidenciam, de forma geral, uma nova reestruturação da ordem local em todos os espaços de inserção dessa cadeia produtiva.

Do ponto de vista da aplicação técnica, salientamos que ela está ocorrendo concomitantemente à (des)reestruturação local no âmbito do capital e do trabalho, pois os novos imperativos hegemônicos da economia global têm impactado negativamente as formações socioeconômicas de populações nativas, tradicionais e camponesas anteriormente estruturadas e cujas produções econômicas não são voltadas exclusivamente para o mercado. Por sua vez, os segmentos da cadeia têm exigido novas dinâmicas socioespaciais campo/cidade em incrementos técnicos relacionados à produção, ao adensamento e à inovação dos fluxos de produtos, à qualificação e à hierarquização do trabalho e às novas relações sociedade/natureza.

No âmbito da cadeia, pudemos verificar que as características concernentes ao território usado se organizam em diferentes níveis tecnológicos e em diversas etapas, escalaridades, territorialidades e hierarquias em um acontecer solidário (SANTOS, 2006), principalmente entre a produção de mudas de eucalipto, as 
áreas de produção das florestas e o processamento industrial, sendo que em cada nível há diferentes graus de fluidez em relação ao transporte.

Como toda cadeia produtiva é diversa e complexa, esta não é diferente, embora deva ser observada e analisada em sua particularidade e singularidade. Neste sentido, o que apresentamos aqui, de forma panorâmica, expressa-se de forma rápida e constante quanto aos novos impulsos e aos novos incrementos tecnológicos e de capitais, podendo mudar em seus principais elementos constituintes, já que obedece à velocidade da ordem global. Dessa forma, a tendência é de aumento da produção de mudas, das áreas de plantio e da escala de processamento, provocando novas reestruturações da ordem local/global obedientes à lógica geral dos espaços das cadeias produtivas.

Nesta lógica, vale destacar os agentes hegemônicos que detêm os processos inicial e final dessa cadeia em nível local, já que sua lógica econômica é global: Viveiro Marka Florestal, Suzano Celulose, Eco Brasil Florestas e SINOBRAS. Estes agentes imprimem técnicas de ponta, seja na criação de espécies de eucalipto, seja na produção e no processamento industrial, dispondo, para tais processos, de grandes investimentos de capital, de forma a garantirem os padrões de qualidade inerentes à cadeia em sua totalidade. Na perspectiva do que Santos (2006) chama de motor único da economia global, destaca-se que tais agentes são portadores das características de empresas globais em escala local, pela sua capacidade de articular, de inovar, de comercializar e de integrar redes da cadeia em questão.

Assim sendo, afirmamos que a abordagem da cadeia da silvicultura do eucalipto da Região Geográfica Intermediária de Araguaína pode ser estudada tendo como ponto de partida qualquer um dos segmentos elencados ao longo do texto. O fato de termos partido da observação do segmento do eucalipto propriamente dito - sendo este, em nossa observação, o fenômeno aparentemente mais expressivo da cadeia - não significa que ele seja o caminho único e necessário de abordagem empírica.

O ponto de partida, portanto, poderia ser qualquer outro segmento, como a fábrica da Suzano, em Imperatriz (MA), a Viveiro Marka Florestal, em Carolina (MA), ou a SINOBRAS, em Marabá (PA), considerando a natureza produtiva de uma cadeia como uma unidade fecunda que se complementa e interage em seus segmentos e níveis técnicos funcionais de produção em espacialidades e em escalaridades diversas; constatação esta que nos convoca a lançar futuros olhares, em ângulos diversos, com o objetivo de produzir novas reflexões para o aprofundamento do fenômeno. 


\section{REFERÊNCIAS}

ABRAF. Anuário estatístico da ABRAF. Brasília, DF: ABRAF, 2012. 150 p.

BATISTA, V. Fábrica de produção de eucalipto é inaugurada nesta quinta em Imperatriz. Correio Brasiliense, Brasília, DF, 20 mar. 2014. Seção Economia. Disponível em: https://www.correiobraziliense.com.br/app/noticia/economia /2014/03/20/internas_economia,418515/fabrica-de-producao-de-eucalipto-einaugurada-nesta-quinta-em-imperatriz.shtml. Acesso em: 02 dez. 2020.

CARVALHO, E. V.; COELHO, M. C. B.; SOUZA JÚNIOR, M. R.; GIONGO, M. M.; GANASSOLI NETO, E. Evolução do setor florestal no Tocantins. Revista de Política Agrícola, Brasília, DF, Ano XXVIII, n. 1, p. 45-54, jan./mar. 2019.

ELIAS, D. Ensaios sobre os espaços agrícolas de exclusão. Revista NERA, Presidente Prudente, ano 9, n. 8, p. 29-51, jan./jun. 2006.

FORNARO, A. C. Logística e agronegócio globalizado no Estado do Tocantins: um estudo sobre a expansão das fronteiras agrícolas modernas no território brasileiro. 2012. 157 f. Dissertação (Mestrado em Geografia) - Programa de Pós-Graduação em Geografia, Instituto de Geociências, Universidade Estadual de Campinas, Campinas, 2012.

IBGE. Censo 2010. IBGE, Rio de Janeiro, 2010. Disponível em: https:// cidades.ibge.gov.br/. Acesso em: 01 jul. 2018.

IBGE. Divisão regional do Brasil em regiões geográficas imediatas e regiões geográficas intermediárias. Rio de Janeiro: IBGE, 2017.

LINKEDIN. Vista aérea do viveiro da Marka Florestal de produção de mudas de eucalipto na cidade de Carolina (MA). LinkedIn, São Paulo, 2020. Disponível em: https://www.linkedin.com/company/marka-florestal. Acesso em: 20 dez. 20.

MARKA FLORESTAL. Viveiro de produção e comercialização de mudas clonais de Eucalyptus ssp. Carolina: Marka Florestal, 2020. 1 folder.

MATOS, M. R. Políticas de desenvolvimento e povos tradicionais na Amazônia: um estudo sobre a Comunidade Remanescente de Quilombo Grotão quanto aos impactos da chegada do eucalipto. 2018. 141 f. Dissertação (Mestrado em Estudos de Cultura e Território) - Programa de Pós-Graduação em Cultura e Território, Universidade Federal do Tocantins, Araguaína, 2018.

PEMPXÀ. UHE Estreito: agravamento de impactos negativos na vida do povo Apinajé. Acervo Combate Racismo Ambiental, [S. l.], 07 maio 2015. Racismo Ambiental. Disponível em: https:/ / acervo.racismoambiental.net. br/2015/05/07/uhe-estreito-agravamento-de-impactos-negativos-na-vida-dapopulacao-apinaje/. Acesso em: 20 set. 2019. 
SANTOS, M. A revolução tecnológica e o território: realidades e perspectivas. Terra Livre, São Paulo, n. 9, p. 7-17, jul./dez. 1992.

SANTOS, M. Os grandes projetos: sistema de ação e dinâmica espacial. In: CASTRO, E. R. M.; MOURA, E.; MAIA, M. L. S. (org.). Industrialização e grandes projetos: desorganização e reorganização do espaço. Belém: EDUFPA, 1995. p. 13-20.

SANTOS, M. O território e o saber local: algumas categorias de análises.

Cadernos IPPUR, Rio de Janeiro, ano XIII, n. 2, p. 15-26, 1999.

SANTOS, M. A natureza do espaço: técnica e tempo, razão e emoção. 4. ed. 2. reeimp. São Paulo: EDUSP, 2006.

SANTOS, M.; SILVEIRA, M. L. O Brasil: território e sociedade no início do século XXI. 10. ed. Rio de Janeiro: Record, 2008.

SBS. Fatos e Números do Brasil florestal. São Paulo: SBS, 2008.

Disponível em: http://www.celso-foelkel.com.br/artigos/outros/09_2008_ FatoseNumerosdoBrasilFlorestal.pdf. Acesso em: 23 nov. 2019.

SINOBRAS. Relatório de sustentabilidade. Fortaleza: SINOBRAS, 2010. Disponível em: https://www.sinobras.com.br/images/pdf/Relatorio_de_ Sustentabilidade_2010.pdf. Acesso em: 07 fev. 2021.

SUZANO. Histórico. Suzano, São Paulo, 02 jun. 2020. Disponível em: https://ri.suzano.com.br/Portuguese/a-companhia/historico/default.aspx. Acesso em: 24 jan. 2021.

TOCANTINS. Lei $\mathbf{n}^{\mathbf{0}}$ 2.713, de 09 de maio de 2013. Institui o Programa de Adequação Ambiental de Propriedade e Atividade Rural [...]. Palmas: Casa Civil, [2013]. Disponível em: https://www.legisweb.com.br/legislacao/ ?id=254460\#: $\sim:$ text=1\%C2\%BA.,Art.. Acesso em: 15 mar. 2021.

VAMPRÉ, S.; MEDINA, P. Dispensa de licenciamento ambiental para atividades rurais no estado do Tocantins: suporte teórico para um discurso argumentativo. Veredas do Direito, Belo Horizonte, v. 16, n. 34, p. 177- 204, jan./abr. 2019. Disponível em: http://www.domhelder.edu.br/revista/ index. php/veredas/article/view/1254. Acesso em: 13 mar. 2021. 
